\title{
Sudden cardiac death: the dark side of exercise!
}

\author{
Rosa Henriques de Gouveia ${ }^{1 *}$, José C. Ramos $^{2}$ and João Pinheiro ${ }^{3}$ \\ ${ }^{1}$ Forensic Pathology Department, Delegação do Centro, Instituto Nacional de Medicina Legal e Ciências Forenses, I.P. and Anatomical-Pathology Professor, \\ Medical Faculty, Coimbra University, Coimbra, Portugal \\ ${ }^{2}$ Forensic Pathology Department, Delegação do Centro-Madeira Extention, Instituto Nacional de Medicina Legal e Ciências Forenses, I.P, Madeira, Portugal \\ ${ }^{3}$ Forensic Pathology Department, Delegação do Centro, Instituto Nacional de Medicina Legal e Ciências Forenses, I.P, Coimbra, Portugal
}

\begin{abstract}
The authors report the case of an apparently healthy 57-year-old male who died sudden and unexpectedly while running on a treadmill in a gymnasium. Postmortem examination revealed an "Ischæmic Cardiopathy". Attention is drawn to the risk of exercise (especially if strenuous and non-regular) triggering Sudden Cardiac Death in adults, namely middle-aged or elderly, with or without known underlying pathology.
\end{abstract}

\section{Introduction}

Sudden Cardiac Death (SCD) is defined as "a natural, unexpected fatal event, with a cardiac underlying cause, occurring instantly or within $1 \mathrm{~h}$ from the onset of symptoms in an apparently healthy subject or whose disease was not so severe as to predict an abrupt outcome" [1]. When not witnessed, it is assumed sudden if "the deceased was in good health $24 \mathrm{~h}$ before death" [1]. Sudden Adult Death is the one occurring in persons aged $\geq 35$ years [2] and Sudden Young Adult Death corresponds to the one happening in persons aged $\geq 18$ to $<35$ years [3]. In non-selected populations, the incidence of Sudden Cardiac Death ranges $0.001-0.002 \%$ per year [4]. In athletes, SCD is rare (1: $50,000-100,000$ annually), yet it is esteemed to occur 2 to 4 times more often than in non-athletes [4]; defining Athlete as "who participates in individual or collective sports (any age) as well as training programme of systematic and regular competitions" [4]. Variations in athletes' SCD epidemiology and cause exist due to age, gender, and populational affinity of subgroups, due to individuals' physiological characteristics or eventual known or unknown co-morbidities, as well as due to type and schedule of exercise / training / sports modality [5]. The authors report and discuss a case where exercise triggered unexpected sudden death of cardiac aetiology in an apparently healthy middle-aged male.

\section{Case report}

\section{History}

A 57-year-old male, with no relevant personal or familial pathologic antecedents and no addiction habits, died unexpectedly while running on a 'gymnasium treadmill'. Unsuccessful resuscitation manœuvers were performed for 20 minutes. Afterwards, witnesses told that he had been practicing an excessive physical activity for about 1 hour and his wife reported that, for 2 days, he had been exercising far beyond the usual. A complete postmortem examination was performed.

\section{Autopsy findings}

Body of a middle-aged male with normal height and weight for age and gender. External Habitus examination showed no traumatic or other significant lesions. Internal Habitus examination revealed generalized and severe vascular congestion of tissues and organs. The heart presented increased weight (450g), normal shape, no congenital malformations and, in section, macroscopic white and firm myocardial foci/areas and white-yellowish eccentric atherosclerotic lesions, occluding $50-75 \%$ of coronary arteries lumen. Organ samples were procured for microscopic examination. They were fixed in $10 \%$ formalin and embedded in paraffin. Microtome sections were stained with haematoxylin/eosin (H/E). Additional special stains [Masson Trichrome (MT), Elastic van Gieson (EvG)] were performed on the heart samples, for better interpretation. Photography of the histological slides was done using LEICA DM1000 LED microscope and image acquisition system LEICA ICC50 HD camera plus LAS EZ v2.0.0 for Windows software. Histopathological evaluation confirmed the generalized vascular congestion of all the organs and showed myocardial fibres hypertrophy, replacement fibrous scars (Figures 1 and 2) and thick walled intra-myocardial arteries at the edge of the scars (Figures 3). It also showed the atherosclerotic plaques to be type IV lesion of "American Heart Association" (A.H.A.) Classification [6,7] (Figures 4). Toxicological tests in the blood, from the heart and femoral vein, were negative for alcohol, drugs and medication. The final diagnosis was that of a "natural cause of death, sudden and unexpected, due to Ischæmic Cardiopathy".

\section{Epidemiological setting}

This case belongs to a series of 1141 autopsies performed during one year (2011) in a Medico-Legal Institution that serves a territorial area of $29.206 \mathrm{Km}^{2}$ with a population of 2.595 .540 inhabitants.

Correspondence to: Rosa Henriques de Gouveia, Forensic Pathology Department, Delegação do Centro, Instituto Nacional de Medicina Legal e Ciências Forenses, I.P, Largo da Sé Nova, 3000-213, Coimbra, Portugal, Tel: +351962685650; E-mail-rhgouveia@mail.telepac.pt

Key words: age, anatomical-pathology, exercise, sudden cardiac death

Received: August 22, 2016; Accepted: September 19, 2016; Published: September 23,2016 


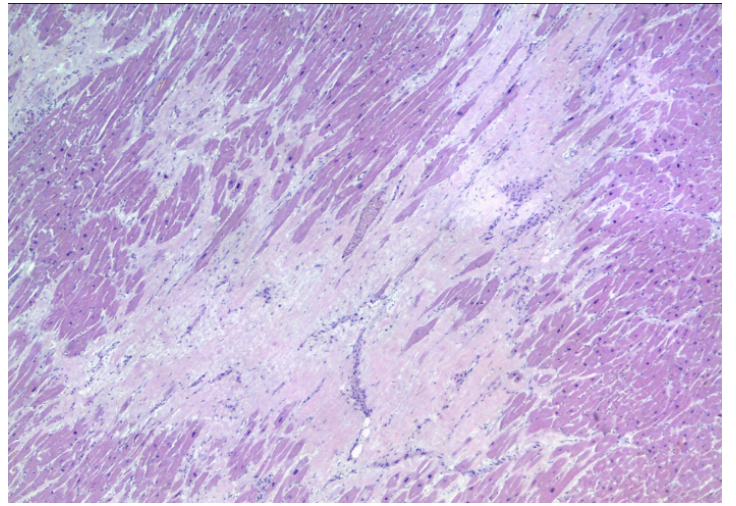

Figure 1. Histopathologic features of "Ischæmic Cardiopathy". View of the left ventricle myocardium with myocardial fibres hypertrophy and replacement fibrous scar [H/E x40] (source: INMLCF, I.P.).

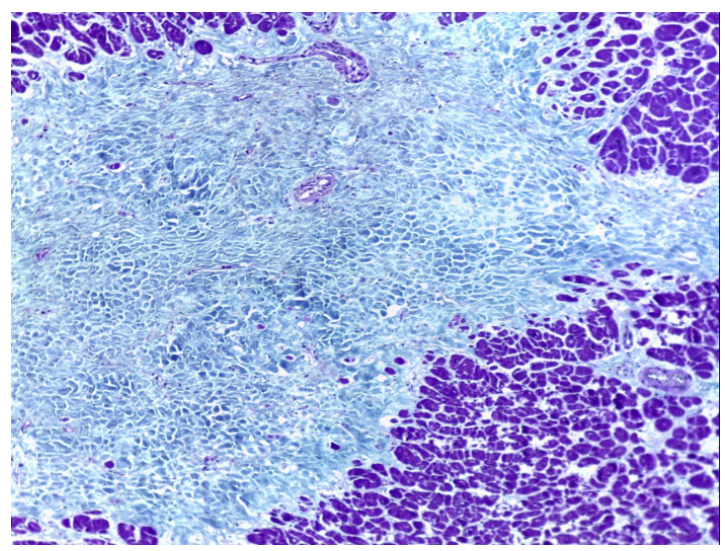

Figure 2. Higher magnification to better show a fibrous scar, due to non-recent ischæmic myocardial destruction and replacement by fibrous tissue [MT x100] (source: INMLCF, I.P.).

\section{Discussion and conclusion}

Physical Activity, either due to profession, to hobbies or to sports practice is beneficial for health, leading to morbidity (cardiovascular, respiratory, endocrine, neurological, musculoskeletal, oncological, etc.) reduction and, thus, mortality decreases [8]. A classical example is the study performed by Morris et al., that showed $50 \%$ less coronary artery disease in physically active professionals [9]. This is very important when we realize that cardiac arrest and sudden death of adults, more frequent in males and increasing with age (middle-age, elderly) [2], are mostly due to cardiovascular pathology, particularly Atherosclerotic (Ischemic) Coronary Heart Disease [10], which ranges from 50,1\% to $60 \%$ in the western world including Portugal $[2-11,12]$. Yet, we must keep in mind the "sports (exercise) paradox", meaning that 'vigorous, acute and transient' physical activity may, on the contrary, be responsible for Sudden Cardiac Death [13], as happened to the victim reported. In fact, strenuous when compared to moderate-intensity exercise was related to a 5 to 7 times higher possibility of unexpected death [14]. Ninety per cent of SCD in sport occur in males and $>90 \%$ in recreational athletes [8], matching our victim's pattern. The major cause underlying Sudden Cardiac Death in older athletes ( $\geq 35$ years) is Atherosclerotic (Ischomic) Coronary Heart Disease - acute or chronic - and its complications $(80 \%)[4,5]$; growing from percentages around $43 \%$ in the older young adults $[3,5]$. In the present case, the mechanisms proposed for the exitus letalis are: 1) "decreased blood flow" due to atherosclerotic reduced lumen of the epicardial coronary arteries and reduced lumen of the aging and/or chronic ischæmiainduced thicken-walled intra-myocardial arteries; which in a setting of physical effort would be insufficient for the myocardial work-load needs, leading to ischemia and/or arrhythmia. 2) "Arrhythmogenic foci" corresponding to the replacement fibrous scars, which interfere with the normal electric cardiac conduction. 3) "Impaired Cardiac Function" due to myocytes hypertrophy and myocardial replacement fibrous scars. Now-a-days, cardiovascular screening of young, especially competitive, athletes is viewed as a medical duty; yet, a preparticipation health evaluation, an adequate choice of sports modality and/or exercise intensity, followed by regular medical re-examination of older practitioners is far from sufficient, whether the individual is apparently healthy or presents a known - but stable - cardiovascular disease [14-17]. Many practitioners engage exercise programs without searching for medical screening or counselling.

In conclusion, the authors draw attention to the following important issues:

1) Individuals who practice physical activity less often and irregularly are at higher risk for sudden death than those who are regular practitioners.

2) Extreme physical activity may lead to a fatal outcome, mainly in persons with cardiac pathology, even if concealed and asymptomatic.

3) Ischæmic Cardiopathy is responsible for $80 \%$ of Sudden

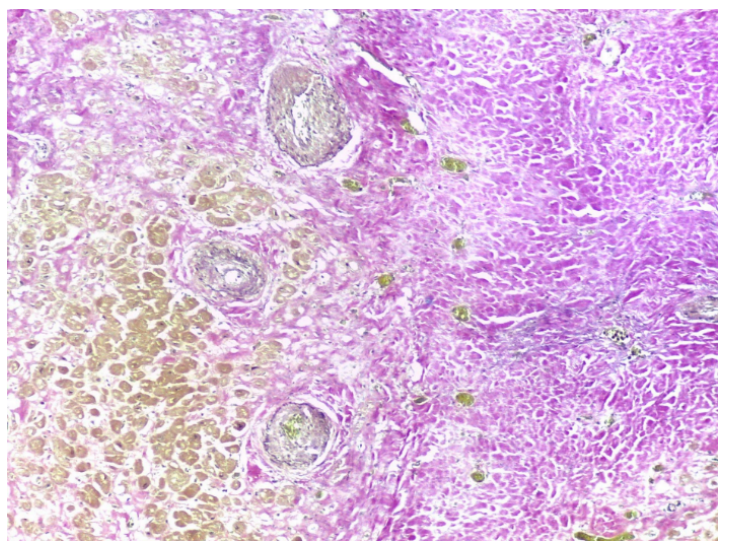

Figure 3. Area with thicken-walled arteries at the interface between the fibrous scar (right) and the adjacent myocardium (left) [EvG x100] (source: INMLCF, I.P.).

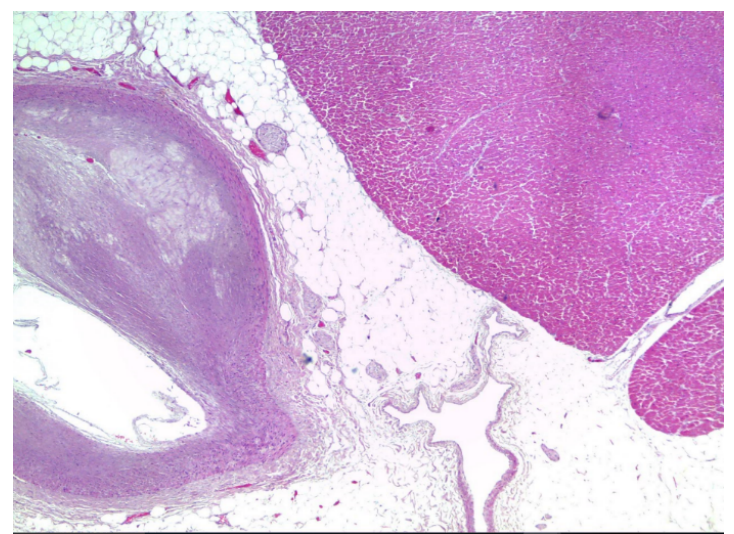

Figure 4. Coronary artery with eccentric type IV (A.H.A.) atherosclerotic lesion, reducing the lumen $50-75 \%$ [H/E x40] (source: INMLCF, I.P.). 
Cardiac Deaths of older athletes.

4) In an era where "physical status" and the search for "eternal youth" are a priority, care must be taken by each individual per se as well as by the society as a whole and the Public Health System to adequate the needs to the possibilities of each person initiating a sports activity, in order to avoid sudden and unexpected fatalities, even when correct out-of-hospital resuscitating manœuvers are performed.

\section{Acknowledgements}

To the Institute National de Medicina Legal e Ciências Forenses, I.P.

\section{Conflict of interest statement}

The authors declare no financial interests or other conflict of interest in relation to the work submitted.

\section{References}

1. Basso C, Burke M, Fornes P, Gallagher PJ, de Gouveia RH, et al. (2008) Guidelines for autopsy investigation of sudden cardiac death. Virchows Arch 452: 11-18. [Crossref]

2. de Gouveia RH, Martins A, Vieira DN. (2015) Sudden Death as the Outcome of Cardiac Arrest, in a Portuguese Region: Where Do Resuscitation Manœuvres Stand? World Journal of Cardiovascular Diseases 5: 227-232.

3. Henriques de Gouveia R, van der Wal AC, van der Loos CM, Becker AE (2002) Sudden unexpected death in young adults. Discrepancies between initiation of acute plaque complications and the onset of acute coronary death.Eur Heart J 23: 1433-1440. [Crossref]

4. Ferreira M, Santos-Siva PR, Abreu LC, Valenti VE, Crispim V, et al. (2010) Sudden cardiac death athletes: a systematic review. Sports Medicine, Arthroscopy, Rehabilitation, Therapy \& Technology 2: 19-24.

5. Schmied C, Borjesson M (2014) Sudden cardiac death in athletes. J Intern Med 275: 93-103. [Crossref]
6. Stary HC, Chandler AB, Glagov S, Guyton JR, Insull W Jr, et al. (1994) A definition of initial, fatty streak, and intermediate lesions of atherosclerosis. A report from the Committee on Vascular Lesions of the Council on Arteriosclerosis, American Heart Association. Arterioscler Thromb 14: 840-856. [Crossref]

7. Stary HC et al. (1995) A definition of advanced types of atherosclerotic lesions and a histological classification of atherosclerosis. Circulation 92: 1355-1374.

8. Sharma S, Merghani A, Mont L (2015) Exercise and the heart: the good, the bad, and the ugly. Eur Heart J 36: 1445-1453. [Crossref]

9. MORRIS JN, HEADY JA, RAFFLE PA, ROBERTS CG, PARKS JW (1953) Coronary heart-disease and physical activity of work. Lancet 265: 1111-1120. [Crossref]

10. The Heart. In: Kumar V, Abbas A, Fausto N, Aster J (2010) Robbins and Cotran Pathologic Basis of Disease. (8thedn), Saunders - Elsevier, Philadelphia.

11. Nolan JP, Soar J, Zideman DA, Biarent D, Bossaert LL, et al. (2010) European Resuscitation Council Guidelines for Resuscitation 2010 Section 1. Executive summary. Resuscitation 81: 1219-1276. [Crossref]

12. Soares-Oliveira M, Ramos R (2014) [Implementation of a national automated external defibrillator program in Portugal]. Rev Port Cardiol 33: 323-328. [Crossref]

13. Marijon E, Uy-Evanado A, Reinier K, Teodorescu C, Narayanan K, et al. (2015) Sudden cardiac arrest during sports activity in middle age. Circulation 131: 1384-1391. [Crossref]

14. Oh DJ, Hong HO, Lee BA (2016) The effects of strenuous exercises on resting heart rate, blood pressure, and maximal oxygen uptake. J Exerc Rehabil 12: 42-46. [Crossref]

15. Jamnik VK, Warburton DER, Makarski J, Mckenzie DC, Shephard RJ, et al. (2011) Enhancing the effectiveness of clearance for physical activity participation: background and overall process. Appl. Physiol. Nutr. Metab. 36: S3-S13.

16. Goodman JM, Thomas SG, Burr J (2011) Evidence-based risk assessment and recommendations for exercise testing and physical activity clearance in apparently healthy individuals. Appl Physiol Nutr Metab 36 Suppl 1: S14-32. [Crossref]

17. Thomas SG, Goodman JM, Burr JF (2011) Evidence-based risk assessment and recommendations for physical activity clearance: established cardiovascular disease. Appl Physiol Nutr Metab 36 Suppl 1: S190-213. [Crossref]

Copyright: (C2016 Gouveia RH. This is an open-access article distributed under the terms of the Creative Commons Attribution License, which permits unrestricted use, distribution, and reproduction in any medium, provided the original author and source are credited. 